\title{
Ectopic pregnancy
}

\section{Better diagnostic methods but still nothing perfect}

The incidence of ectopic pregnancy has increased in recent years in several industrialised countries. ${ }^{2}$ In the United States in the past 14 years there has been a fourfold increase in incidence but a sevenfold decrease in deaths. ${ }^{3}$ In Britain ectopic pregnancy has increased, but as national figures are not available we cannot determine with accuracy the decrease in morbidity. Ectopic pregnancy still accounts for about $10 \%$ of maternal deaths, even in developed countries with immediate access to blood transfusion, complex diagnostic tests, ultrasonography, and surgery.

Atrash et al reporting on deaths from ectopic pregnancy during 1940-76 and 1977-83 in the United States found that $88 \%$ of patients died from bleeding, $5.4 \%$ received no treatment, and in more than half gestation was less than 10 weeks. ${ }^{4}$ Deaths from ectopic pregnancy decreased throughout all regions of the United States but was still three times commoner in non-whites than whites. Many of these women died at home for reasons that included misdiagnosis and failure to contact a doctor early enough. ${ }^{5}$

The causes of ectopic pregnancy are complex, but previous pelvic sepsis, an earlier ectopic pregnancy, and tubal surgery are associated with ectopic pregnancy. ${ }^{6}$ The contribution of pelvic inflammatory disease to ectopic pregnancy is not clear: Niles and Clark in 1969 reported pelvic inflammatory disease in only two fifths of cases, ${ }^{7}$ whereas Breen in 1970 reported it in $90 \% .{ }^{8}$ The recent explosion of pelvic inflammatory disease has resulted in a dramatic increase in reported cases, and sexually transmitted disease accounts for up to four fifths of tubal infections in women under $25.9^{10}$ The tubal infection is usually polybacterial ${ }^{9112}$ and may be asymptomatic or mild. ${ }^{13} 14$

The classic clinical picture of ectopic pregnancyamenorrhoea of eight to 10 weeks, severe abdominal pain, abdominal tenderness, and possibly an adnexal mass with shock if the pregnancy has ruptured-has changed in recent years. The change has occurred because of the greater availability of diagnostic tests, earlier referral of patients, and patients' better awareness and understanding of ectopic pregnancy.

In recent studies up to $97 \%$ of patients with an ectopic pregnancy complained of pain even before tubal rupture, and $93 \%$ had amenorrhoea or a history of abnormal menstruation, whereas half to four fifths had irregular bleeding that was usually mild and intermittent. ${ }^{15}{ }^{16}$ On examination abdominal tenderness was present in most cases (up to 95\%) and an adnexal mass in $63 \%$-but a fifth of patients may have an adnexal mass on the side opposite the ectopic pregnancy, usually a corpus luteum cyst. Surprisingly, cervical excitation pain was present in only half of the patients; vaginal bleeding was more common, occurring in almost three quarters of them. The uterus was soft and normal in size in about three quarters of the patients and enlarged up to the size of a gestation of eight weeks in just under a third. ${ }^{17}$

The history and clinical signs of ectopic pregnancy may therefore be the same as in other gynaecological conditions such as salpingitis, a ruptured corpus luteum cyst, or even threatened or incomplete miscarriage. An ectopic pregnancy may also have to be considered in the differential diagnosis of appendicitis, endometriosis, a degenerating fibroid, and dysfunctional uterine haemorrhage.

The accuracy of a purely clinical diagnosis in ectopic pregnancy is about half. ${ }^{814}{ }^{15}$ It is therefore essential to back up the diagnosis with investigations. Several tests have been used alone or in combination in recent years: blood progesterone concentration, ${ }^{18}$ a pregnancy test,${ }^{19}$ a specific test for $\beta$ human chorionic gonadotrophin, ${ }^{20-22}$ culdocentesis, ${ }^{16}$ pelvic ultrasonography, ${ }^{23}$ and laparoscopy. ${ }^{24}$

\section{PREGNANCY TESTS AND HORMONE ASSAYS}

Ectopic trophoblast tissue usually produces less human chorionic gonadotrophin than a normal intrauterine pregnancy; thus the original rapid urine pregnancy tests had an unacceptable high rate of false negative results in diagnosing ectopic pregnancy. ${ }^{25}$ The newer pregnancy tests on urine that use monoclonal antibodies have greater sensitivity and seem to be useful in diagnosing ectopic pregnancy-up to $90 \%$ in one series and $96 \%$ in another. ${ }^{26}{ }^{27}$ These urine tests are more sensitive than assays of serum radiolabelled receptors, ${ }^{28}$ but serum radioimmunoassay is more sensitive still and has given positive results in up to $99 \%$ of cases..$^{29}$ Radioimmunoassay, however, requires specialised equipment and staff and is not readily available to all hospitals at all times.

To be useful a hormone test must be rapid, sensitive, and widely available. Normal intrauterine pregnancy is associated with a doubling of human chorionic gonadotrophin concentrations within $1 \cdot 4$ to $2 \cdot 1$ days in early pregnancy. ${ }^{2031}$ The initial concentration of human chorionic gonadotrophin and the sampling interval does not seem to influence this doubling time, ${ }^{20}$ but only two thirds to three quarters of cases of ectopic pregnancy could be diagnosed with this method: ${ }^{31}{ }^{32}$ Recently 
ultrasensitive immunofluorometric assays have been developed that require only 10 minutes' incubation time and are simple to use. ${ }^{33}$ They are so sensitive that patients with a positive result have had a laparoscopy or laparotomy that has failed to show an ectopic pregnancy and yet later the diagnosis has been confirmed and another operation has been needed. ${ }^{21}$

Serum progesterone concentrations are also lower in ectopic pregnancy than in normal pregnancy. . $^{34-36}$ Yeko et al have recently investigated a rapid radioimmunoassay for serum progesterone concentration using a cut off value of $15 \mathrm{mg} / \mathrm{ml}$ : all 24 patients with intrauterine pregnancies had values above this, while the 28 with ectopic pregnancies and 17 of the 18 with abnormal intrauterine pregnancies (eventually ending in spontaneous abortion) had values lower than $15 \mathrm{mg} / \mathrm{ml} .{ }^{18} \mathrm{~A}$ single serum progesterone value with this cut off point would therefore seem to be a useful diagnostic test.

\section{CULDOCENTESIS}

Needle aspiration of the pouch of Douglas through the posterior vaginal fornix has been widely used in the United States and in some parts of Europe but less commonly in England to diagnose ectopic pregnancy. ${ }^{16} \mathrm{~A}$ positive diagnosis depends on aspirating non-clotting blood with a haematocrit value of over $5-10 \%$. Unfortunately false positive results vary from $5 \%$ to $10 \%$ because of a ruptured corpus luteum, retrograde menstruation, incomplete abortion, or endometriosis. False negative results are also high $\left(10-14 \%{ }^{25}\right)$ and may occur with an intact unruptured ectopic pregnancy or when blood loss is small. Also, in those with a positive result, only about four fifths have ectopic pregnancies. ${ }^{37} 38$

\section{ULTRASONOGRAPHY}

Pelvic ultrasonography has been used for many years in the early diagnosis of intrauterine pregnancy. ${ }^{23}$ The resolution of the machines has, however, limited its application to tubal pregnancy; all the doctor has been able to do is to suspect an ectopic pregnancy when the woman has symptoms of pregnancy, but ultrasonography does not show an intrauterine pregnancy. In practice an intrauterine pregnancy rules out an ectopic pregnancy: they coexist in only one in 30000 unstimulated pregnancies. ${ }^{39} \mathrm{~A}$ pseudogestation sac may, however, be visible inside the uterus with an ectopic pregnancy. ${ }^{40-42}$ An ectopic pregnancy is confirmed if an ectopic gestation sac with fetal heart movements can be shown on ultrasonography, but this is present in only $5-19 \%$ of patients ${ }^{41}$-and early clinical presentation rules it out in many cases.

Another appearance on ultrasonography may be a complex mass that is solid or cystic and represents a pelvic haematocoele, which may be distinguished from a simple ovarian follicular cyst but may be confused with fibroids or a hydrosalpinx.

Free fluid in the peritoneal cavity, especially in the pouch of Douglas or higher in the pelvis, is often diagnostic of ectopic pregnancy but needs to be differentiated from the smaller volumes of fluid that occur, for example, with pelvic inflammatory disease and at ovulation. ${ }^{23}$ Mahony et al found a fifth of women with surgically confirmed ectopic pregnancy had normal ultrasonographic adnexal findings, ${ }^{43}$ while Gleicher et al in a small series correctly diagnosed $89 \%$ of ectopic pregnancies. ${ }^{44}$

\section{LAPAROSCOPY}

One of the main reasons for the decrease in morbidity from ectopic pregnancy has been the widespread use of laparoscopy since the late 1960s. The procedure usually allows good visualisation of the pelvis and provides a positive diagnosis in more than $90 \%$ of patients. $^{45}$ False positive results have, however, been reported in up to $5 \% .^{46}$

\section{CONCLUSIONS}

How then should we make the diagnosis of an ectopic pregnancy? The wary doctor will suspect the diagnosis when some of the clinical signs and symptoms are present. No single test is absolutely reliable, and a combination of tests will give the best prediction. In patients who are not seriously ill a sensitive assay of human chorionic gonadotrophin concentration with pelvic ultrasonography to exclude an intrauterine pregnancy will allow the doctor to decide whether to proceed immediately to laparoscopy or wait. If the results are equivocal a repeat assay after 48 hours allows the doubling of time of the human chorionic gonadotrophin concentration to be assessed. A single blood progesterone concentration needs further evaluation but looks promising as a diagnostic hormonal test. In patients who are more seriously ill with positive results on rapid assay for human chorionic gonadotrophin concentration and negative results on pelvic ultrasonography laparoscopy will be the definitive investigation. Though these tests in patients with still more severe symptoms may be helpful, the doctor will tend to move more quickly to laparoscopy and even laparotomy.

These diagnostic tests have contributed greatly to the decline in mortality from ectopic pregnancy. Even better awareness of the signs of ectopic pregnancy among patients and doctors and the identification of groups at risk should lead to a further reduction in morbidity and mortality.

Professor and Head of Department of

JOHN NEWTON

Obstetrics and Gynaecology,

Birmingham Maternity Hospital,

Birmingham B15 2TG

1 Rubin GL, Petersen HB, Dorfman SF, et al. Ectopic pregnancy in the United States: 1970 through 1978. FAMA 1983;249:1725-9.

2 Beral V. An epidemiologic study of recent trends in ectopic pregnancy. $\mathrm{Br} J$ Obstet Gynaecol 1975;82:775-82.

3 Centers for Disease Control. Ectopic pregnancy in the USA: 1970-1983, CDC surveillance summaries. MMWR 1986;35:29.

4 Atrash HK, Friede A, Hogue CJR. Ectopic pregnancy mortality in the United States, 1970-1983. Obstet Gynecol 1987;70:817-22.

5 Dorfman SF, Grimes DA, Cates W Jr, Binkin NJ, Kafrissen ME, O'Reilly KR. Ectopic pregnancy mortality, United States, 1979 to 1980: clinical aspects. Obstet Gynecol 1984;64:386-90.

6 World Health Organisation. Mechanism of action, safety and efficacy of IUDs. Geneva; WHO, 1987. (WHO Technical Report Series 753.)

7 Niles JH, Clark JFJ. Pathogenesis of tubal pregnancies. Am O Obstet Gynecol 1968;105:1230-8.

8 Breen JL. A 21 year survey of 654 ectopic pregnancies. Am 7 Obstet Gynecol 1970;106:1004-12.

9 Sweet RL, Gibbs RS, eds. Infectious disease of the female genital tract. Baltimore: Williams and Wilkins, 1985:53-77.

10 Mardh PA, Lind A, Svensson L, Westrom L, Moller BR. Antibodies to Chlamydia trachomatis Mycoplasma hominis and Neisseria gonorrhoea in sera of patients with acute salpingitis. British Journal of Venereal Diseases 1981;57:125-9.

11 Ledger W, ed. Infection in the female. Philadelphia: Lea and Febiger, 1986:9-34.

12 Eschenbach D, Buchanan TM, Pollock HM. Polymicrobial etiology of acute pelvic inflammatory disease. $N$ Engl I Med 1975;293:166-71.

13 Tunnonen R, Terho P, Nikkanen V, Meurman O. Chlamydial serology in infertile women by immunofluorescence. Fertil Steril 1979;31:656-9.

14 Gump DW, Gibson M, Ashikaga T. Evidence of prior pelvic inflammatory disease and its relationship to Chlamydia trachomatis antibody and intrauterine device use in infertile women. Am J Obstet Gynecol 1983;146:153-9.

15 Tuomivaara L, Kauppila A, Puolakka J. Ectopic pregnancy_an analysis of the etiology, diagnosis and treatment in 552 cases. Archives of Gynecology 1986;237:135-47.

16 Weckstein LN. Clinical diagnosis of ectopic pregnancy. Clin Obstet Gynecol 1987;30:236-45.

17 Brenner PF, Roy S, Mishell DR. Ectopic pregnancy: a study of 300 consecutive surgically treated cases. ЭAMA 1980;243:673-6.

18 Yeko TR, Gorrill MW, Hughes LH, Rodi A, Bustan SE, Sauer MV. Timely diagnosis of early ectopic pregnancy using a single blood progesterone measurement. Feril Steril 1987;48: 1048-50. 19 Hogston P. How should we diagnose ectopic pregnancy? Journal of Clinical Practice 1987;41 609-11.

$20 \mathrm{Kadar}$ N, Romero R. Observation on the log hCG time relationship in early pregnancy. Am $\mathcal{F}$ Obstet Gynecol 1987;157:73-8

21 Seppala $M$, Parhonen $M$. The use of $\mathrm{hCG}$ and other pregnancy proteins in the diagnosis of ectopic pregnancy. Clin Obstet Gynecol 1987;30:148-54.

22 Le Maistre A, Bracey A, Katz A Wu AHB. Role of qualitative hCG assays in diagnosis of ectopic pregnancy. Clin Chem 1987;33:1908-10.

23 de Crespigny LC. The value of ultrasound in ectopic pregnancy. Clin Obstet Gynecol 1987;30. 136-47.

24 Chamberlain G, Caron-Brown J, eds. Gynaecological laparoscopy. Report on the working party of the confidential enquiry into gynaecological laparoscopy. London: Royal College of Obstetricians and Gynaecologists, 1978.

25 Weckstein LN. Current perspective of ectopic pregnancy. Obstet Gynecol Surv 1985;40:259-65.

26 Barnes BB, Roy Y, Yec B, et al. Reliability of urinary pregnancy tests in the diagnosis of ectopic pregnancy. I Reprod Med 1985;30:827-31.

27 Nordenskjold F, Aklgress M, Erneth L, Hultberg B. A sensitive urine pregnancy test as an aid in the diagnosis of ectopic pregnancy. Fertil Steril 1985;43:748-52. 
28 Berry CM, Thompson JD, Hatcher R. The radio receptor assay for hCG in ectopic pregnancy. Obstet Gynecol 1979;54:43-6.

9 Schwart RO, De Pietro DL. Beta-hCG as a diagnostic aid for suspected ectopic pregnancy. Obstet Gynecol 1980;56:197-9.

30 Phipps JJ, Naftalin NJ. Ectopic pregnancy diagnosed by measurement of hCG but not laparotomy. Lancet 1986;i:552.

1 Pittaway DE, Reish RL, Wentz AD. Doubling times of hCG increase in early viable pregnancies. Am J Obstet Gynecol 1985;152:299-303.

$32 \mathrm{Kadar}$ N, De Vore G, Romero R. Discriminatory hCG zone: its use in the sonographic evaluation for ectopic pregnancy. Obstet Gynecol 1981;58:156-61.

33 Stenman UH, Alfthan H, Myllyness L, Seppala M. Ultrarapid and sensitive time resolved fluoroimmunometric assay for $\mathrm{hCG}$. Lancet 1983;ii:647-9.

34 Milwidsky A, Segar S, Menasbe M, Adori A, Palti A. Corpus luteum in ectopic pregnancy. Int $\mathcal{F}$ Fertil 1984;29:244-7.

35 Radwanska E, Frankenberg J, Allen EI. Plasma progesterone levels in normal and abnormal early human pregnancy. Fertil Steril 1978;30:398-402.

Mathews CP, Goulson PB, Wild RA. Serum progesterone levels as an aid to the diagnosis of ectopic pregnancy. Obstet Gynecol 1986;68:390-4.
37. Romero R, Copel NA, Kadar N, Jeauty P, Decherney A, Hobbins JC. Value of culdocentesis in the diagnosis of ectopic pregnancy. Obstet Gynecol 1985;65:519-22.

Weckstein LN, Boucher AR, Tucker H, Gibson D, Rettenmaier MA. Accurate diagnosis of early ectopic pregnancy. Obstet Gynecol 1985;65:393-7.

39 Reece EA, Petrie RH, Sirmans MF, Finster M, Todd WD. Combined intrauterine and extrauterine gestations: review. Am J Obstet Gynecol 1983;146:323-30.

40 Spirt BA, O'Hara KR, Gordon L. Pseudo-gestational sac in ectopic pregnancy: sonographic and pathologic correlation. Fournal of Clinical Ultrasound 1981;9:338-43.

41 Robinson HP, de Crespigny LC. Ectopic pregnancy. Clin Obstet Gynecol 1983;10:407-12.

42 Webster HD Jr, Barclay DL, Fischer CK. Ectopic pregnancy: a seventeen year review. Am 7 Obstet Gynecol 1965;92:23-34

43 Mahony BS, Filly RA, Nyberg DA, Callen PW. Sonographic evaluation of ectopic pregnancy. I Ultrasound Med 1985;4:221-9.

44 Gleicher N, Giglia RV, Deppe G, Elrad H, Friberg J. Direct diagnosis of unruptured ectopic pregnancy by real-time ultrasonography. Obstet Gynecol 1983;61:425-8.

$45 \mathrm{Kim}$ DS, Chung SR, Park MI, Yim YP. Comparative review of diagnostic accuracy in tubal prim DS, Chung SR, Park MI, Yim YP. Comparative review of diagn

pregnancy: a 14 year survey of 1040 cases. Obsret Gynecol 1987;70:547-54.

46 Gonzalez FA, Waxman M. Ectopic pregnancy. Diagnostic Gynecology and Obstetrics 1981;3:101-9.

\section{Genes on the $\mathrm{X}$ and $\mathrm{Y}$ chromosomes controlling sex}

\section{Genetic sex is a matter of quantity}

The way in which differentiated tissues arise from pluripotent cells in the embryo remains mysterious. Gene regulation is the key, of course, and much is being learnt about, for example, the control of transcription by DNA binding proteins. ${ }^{1}$ The sex difference is an example of differentiation that might be expected to yield answers if only because many species, including man, have heteromorphic sex chromosomes that segregate to offspring in a predictable fashion. But the segregation is not quite predictable: in our own species there are exceptions to the $\mathrm{X}-\mathrm{Y}$ sex determining system, and these interesting exceptions are now providing answers to questions about the initiation of mammalian sex differentiation.

To understand the importance of these findings we must go back to the late 1950 s, when it was confirmed that males had a $46, \mathrm{XY}$ and females a 46, XX karyotype. In both mouse and man XO was found to be female and XXY to be male, indicating the dominant role of the $\mathrm{Y}$ chromosome in the differentiation of the testis. ${ }^{23}$ This was a surprise to some because in Drosophila melanogaster and some other invertebrates sex was known to be determined by the ratio of $\mathrm{X}$ chromosomes to autosomes-thus XOs were male and XXYs female. ${ }^{4}$

Study of correlations between karyotypes and phenotypes in chromosomal variants of Klinefelter's and Turner's syndromes soon showed that the testis determining factors, as they were called, were located in the short arm of the Y chromosome ${ }^{5}$; those without this segment in at least some cells were invariably female. Somatic cell mosaics with $\mathrm{XX} / \mathrm{XXY}$ and $\mathrm{XO} / \mathrm{XY}$ sex chromosome complements and $\mathrm{XX} / \mathrm{XY}$ chimaeras were sometimes intersexes, with both testes and ovaries showing varying degrees of dysgenesis. The most extreme examples of sex reversal were males with Klinefelter's syndrome and an apparently XX female karyotype $^{6}$ and females with gonadal dysgenesis and an apparently XY male karyotype. ${ }^{7}$ The "XX males" and "XY females" were predicted to have gained or lost the testis determining segment as a result of accidental recombination between the differential segments of the $\mathrm{X}$ and $\mathrm{Y}$ chromosomes during male meiosis.

The first clue in favour of such abnormal X-Y interchange was the observation that several XX males had lost the father's $\mathrm{Xg}$ blood group allele in the process. ${ }^{8}$ Later it was shown that one $\mathrm{X}$ chromosome was a little longer than the other ${ }^{9}$ and that the tip of the short arm of the Y could sometimes be seen at the end of one of the $\mathrm{X}$ chromosomes. ${ }^{10}$ Conclusive proof came from DNA probing, which showed that many XX males not only had specific sequences from the short arm of the $\mathrm{Y}^{11}$ in the distal end of the short arm of the $\mathrm{X}^{12}$ but also had lost $\mathrm{X}$ sequences. ${ }^{13}$ Conversely, a smaller proportion of $\mathrm{XY}$ females could be shown to have lost short arm sequences of the $\mathrm{Y}$ chromosome. ${ }^{14}$ It became clear that XX males and XY females held the key to sex differentiation. The goal was to clone the gene for testis determination from the DNA of XX males with $\mathrm{X}-\mathrm{Y}$ interchange.

It is now almost certain that this goal has been achieved. Page et al reported last December the details of a likely candidate for the testis determining gene. ${ }^{\text {is }}$ This was cloned from an XX male and was found to be missing from a female who had a reciprocal translocation between the short arm of the $\mathrm{Y}$ chromosome and chromosome 22 that was associated with the loss of a tiny segment (160 kilobases) of the short arm of the $\mathrm{Y}$ chromosome. The gene codes for a protein that contains a series of zinc fingers, a motif characteristic of proteins that bind DNA, which are thought to participate in regulating transcription. Its action on the pathway to differentiation of the testis is unknown, but it might well be the primary sex determining signal.

A key observation in the important paper by Page $e t$ al is that in addition to the $\mathrm{Y}$ linked gene there is apparently a copy of the testis determining gene carried by the short arm of the $\mathrm{X}$ chromosome. This copy is distinguishable by restriction mapping and is located more proximally, where it might be expected to be subject to $\mathrm{X}$ inactivation. Given that the $\mathrm{X}$ homologue codes for the same protein as the $\mathrm{Y}$ homologue, female somatic cells (whether XX, XO, or XXX, and so on) have only one active copy of the gene compared with male cells (whether XY, XXY, XXXY, or XYY), which have at least two. XX males usually have two doses because the $\mathrm{Y}$ homologue is transferred to part of the $\mathrm{X}$ chromosome that escapes inactivation.

The implication of these findings is that our species now falls into line with other species, including Drosophila melanogaster, in which the primary sex determining system depends on active gene dosage. In fact all mammalian species tested are consistent with the dosage system, and even in birds (which have nothing comparable with $\mathrm{X}$ inactivation) it seems likely that the $\mathrm{ZZ}$ male has a double dose of the testis determining gene compared with the $\mathrm{ZW}$ female. It follows that the description testis determining gene is misleading as the same gene leads to ovarian differentiation if present in a single dose. As suggested by German, it would be better to refer to the $\mathrm{X}$ and $\mathrm{Y}$ homologues as gonad differentiating genes and the loci as GDX and GDY, respectively. ${ }^{16}$

Several groups of patients remain in whom unusual gonadal 